\section{Longitudinal Impacts of Home Computer \\ Use in Early Years on Children's Social and Behavioral Development}

\begin{tabular}{ll}
\hline Received: & 10 January 2019 \\
Revised: & 15 January 2019 \\
Accepted: $\quad 20$ January 2019 \\
ISSN: 1307-9298 \\
Copyright (C) IEJEE \\
www.iejee.com
\end{tabular}

Ebrahim Talaee*

\begin{abstract}
This study presents a pattern for Home Computer Use (HCU) and its relation to children's social and behavioural development during primary education. This study answers whether and how HCU (either educational or recreational) during primary school is related to children's social/ behavioural development such as self-regulation, anti-social behaviour and pro-social behaviour. To do so, information about types and frequency of HCU from nearly 2000 children were analysed using hierarchical linear regression and path analysis on children ranging from 3 to 11 years old. Hierarchical linear regression was applied to study the main effects (i.e. direct effects) and the path analysis was used to investigate mediating (i.e. indirect effects) of HCU on children outcomes. The results showed that the use of HCU for playing games has a linear and negative association with children's Pro-social behaviour as reported by class teachers in Year 6 , while the effects of other background characteristics were partialled out. Two other social/behavioural outcomes - anti-social behaviour and self-regulation - were not associated with children's HCU over and beyond what can be predicted based on children's prior social/behavioural profile and their demographic background characteristics. The theoretical and practical implications of these results are discussed.
\end{abstract}

Keywords: APrimary Education, Home Computer Use, Anti-Social Behaviour, Self-Regulation, Social/Behavioural Outcomes

\section{Introduction}

Rapid developments of ICTs, digital media and advanced educational technologies provide opportunities for people to deal with rapidly changing complex problems and issues (see Bose, 2009; Ersoy \& Bozkurt, 2017; Noroozi, 2017; Noroozi \& Mulder, 2017). Such fast developments of technologies have strong consequences for education in all levels from primary schools to university, since they provide learners with a bunch of digital tools to work alone and also cooperate with their learning partners both at formally at schools and informally at home (Coffey, 2017; Huda et al., 2017; Noroozi et al., $2011 ; 2012 ; 2013 a, 2013 b, 2013 c, 2017)$

Scientific research on the effects of media for children express how media can affect children's social and behavioural actions (Wartella, Caplovitz \& Lee, 2004). The 21st century witnesses public debates on the role of digital media such as Home Computer Use (HCU) for children's social/behavioural development. The literature on the relation between $\mathrm{HCU}$ and social/behavioural development is rather limited and the findings are mixed. Most studied aspects of social/ behavioural development are children's social interaction skills (Subrahmanyam et al., 2001), family dynamics and inside-family interactions (Mitchell, 1985), teacher-rated classroom behaviour (Malamud \& Pop-Eleches, 2008), methods of interpersonal communication (Turow, 2000), increased self-regulation and independent learning abilities (Valentine et al., 2005), decline in social and psychological well-being such as increases in loneliness and depression and decreases in communication within the family (Kraut et al., 1998), improved attention skills and greater motivation and engagement (Passey et al., 2003), less pro-social behaviour (Wiegman \& Van Shie, 1998), becoming desensitized to violent and aggressive behaviour due to the blurring real world and simulated virtual environment in the computer games (Turkle, 1995), anti-social and violent behaviour through excessive aggressive games playing (Irwin \& Gross 1995). As the list above shows, the literature on the association between use of digital media and children's social/behavioural development reflects the last century controversies between technology's inspiration for enhancing children's aspects of development and concerns about the risks of exposure to inappropriate content and people.

Theoretical perspective on HCU and social/behavioural development

The academic literature on the theoretical underpinning of the relationship between ICT use and children's social/behavioural development is a continuation of the theoretical controversies on the media effects on individual's behaviour. The last century body of empirical and theoretical investigations on media and society, particularly on television and video games, reflects the debate between those who argued against the negative effects of media on people's social relationships and behaviour (Kraut et al., 1998) and those who were trying to show that the media have positive effects on people's social skills and behavioural outcomes too (Song \& Keller, 2001) or the negative effects are negligible compared to other influencing factors (Shaw \& Gant, 2002). Compared with older generation of media, digital technology of the $21 \mathrm{st}$ century seems to be a more powerful influencer on child's behaviour and social outcomes because, through interactivity characteristics of the new technologies, the children themselves 'actively engage in constructing and acting out social roles' (Wartella et al., 2004, p.10). The advocates of ICT for learning rely on the views of constructivists and socio- constructivists concerning learning with computers (see Säljö, 1998; Noroozi et al., 2016, 2017, 2018). The body of theoretical work on the relationship between new digital technologies and children's social/behavioural development is rather limited because of the novelty of the field and rapidly updating nature of technology and users' technological behaviour. In this section, the main theoretical frameworks put forward for the possible association between ICT use and selected aspects of children's social/behavioural development are discussed. 


\section{ICT use and interpersonal relationships}

The proponents of the idea that the internet use leads to less interpersonal relationships with family and friends and increases loneliness and depression explain this through two influencing factors of time and the differential nature of online social relationship as opposed to faceto-face (FtF) ones. Figure 1 shows this relationship. The time factor roots in studies on the effects of television in the scientific literature particularly the classic study done by Steiner (1963). In his studies, he theorised and empirically showed that television viewing occurs at the expense of socialising; 'the more spend watching television, the less time spent with family, friends and neighbours (Steiner 1963, p.230).

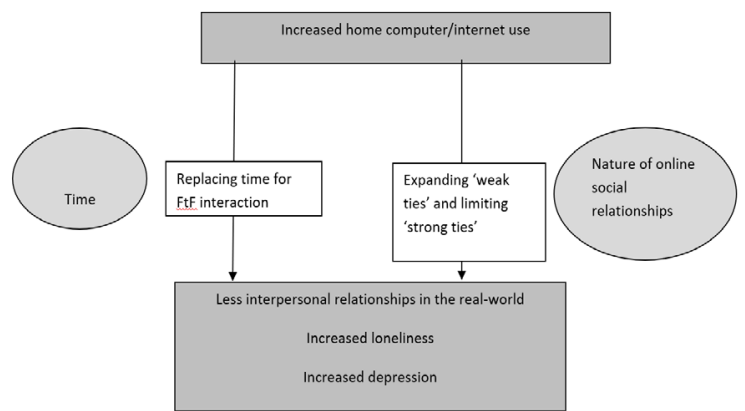

Figure 1. Theoretical explanation of adverse effects of the internet on social relationships

Similar explanation is given for less reported instances of face-to-face interactions of frequent internet users (Nie \& Erbring 2000, Nie 2001; Subrahmanyam et al., 2000). They theorise that there are definitely constraints on one's time and they need to do a trade-off between hours spent on the internet use - even those hours used to communicate with friends and family - and other off-line social activities (PEW, 2000). A large body of empirical evidence supported the theory reporting that the internet time has even decreased the time people watch television, use other media such as talking with friends on the phone (George, 1997) and the time people take part in social events (Lo, Wang \& Fang 2005). However, the time children spend on HCU is drastically increasing with widespread internet access while the overall number of hours of television viewing has not changed on more than a decade (Livingstone et al., 2009). Thus, it might indicate that the internet time comes from the time used to be spent playing and interacting with peers, siblings and parents (Nie \& Erbring, 2000).

Figure 1 shows that another explanation for the negative impact of HCU on children's social relationships could be the differential nature of the interpersonal relationships while being online and in the face-to-face interactions. Initial theories on the differential nature of FtF interactions with those online were put forward in the last two decades when Computer-Mediated Communications (CMC) were diffusing into the workplace (Walther, 1995). Short, Williams and Christie (1976) proposed Social Presence Theory and later Sproull and Kiesler (1986) suggested Lack of Social Context Cues hypothesis to delineate the CMC and FtF social relationships. The former theory holds that the levels of social presence in a relational communication are determined by the medium of communication; 'the fewer the channels within a medium, the less attention is paid by the user to the presence of other social participants' (Walther, 1995, p. 95). As the computer-mediated communications (CMC), particularly of the time, did include a limited number of channels (e.g. only text in emails and not gestures, dress etc), they hypothesised that CMC is extremely low in social presence. Steinfield (1986) then suggested that decline in social presence of an interpersonal relationship leads to the messages to be more impersonal. The impersonal nature of messages through CMC was associated with them to be less intimate and friendly (Culnan \& Markus, 1987), and more likely to be blunt and hostile (Dubrovsky et al., 1991).

The theories reviewed above share the underlying premise that children's nature of social relations through the internet is different to the social interactions they have in the real world. McKenna and Bargh (2000) identified four major differences for online interpersonal relationships: one's greater anonymity, the greatly reduced importance of physical appearance and physical distance as "gating features" to relationship development, and one's greater control over the time and pace of interactions. These differences both help to explain potentially socially isolating impact of extensive HCU and the rival model in which internet is linked to increased social involvement and social support (Shaw \& Gant, 2002). Anonymity, for instance, encourages deindividuation which means that one's self-awareness is extremely reduced by environmental conditions such as presence of a large number of people (McKenna \& Bargh, 2000). Thus, an individual is less likely to care about what others think of his/her behaviour and therefore may behave more bluntly with greater aggressive responses.

On the other hand, the anonymity characteristic of CMC was shown to allow individuals to take greater risks in making disclosures to their internet friends. Moreover, being anonymous on the net was shown to provide children with the opportunity to successfully create and maintain 'wished for changes in their self-concept' (McKenna \& Bargh, 2000, p.45). Anonymity was then hypothesised to enhance opportunities for children to engage in greater identity and role construction and to feel more comfortable for social interactions.

ICT and violent behaviour (anti-social behaviour). Children's aggressive and anti-social play and behaviours are repeatedly associated with their extent of playing computer games (see Browne \& Hamilton-Giachritsis, 2005). The theoretical foundation of much of the work in this field roots back in the rich psychological/sociological literature on the impact of watching violent movies on television on children's behaviour which has produced a thoroughly documented set of studies since started five decades ago (Anderson \& Bushman, 2001). However, studies show that, playing computer games have some important differences with viewing violent scenes on TV. First, the interaction affordances of the new technologies make it possible for users to 'actively' interact with violent imagery - for instance the active interaction of children with characters in today's sophisticated computer games. This is shown to have greater effects on the users because the child plays a more active role through having more control and more rewards for acting aggressively (Colwell \& Payne, 2000). Second, the new video games possess an element of increasing 'realism' and life-like characters and situation which makes them more likely to have effects on children's heightened aggression in the real life (Kirriemuir \& McFarlane, 2006). This might have a greater effect than abstract violence particularly for primary pupils who are developmentally- according to Piaget's stages of cognitive development - at pre-operational phase in which abstract concepts are difficult to understand (Piaget, 1978). A recurrent example for more mature pupils than those who are at the pre-operational phase of cognitive development is the game Grand Theft Auto III in which the player engages in a sexual practice with a prostitute and in a separate act is able to kill her to retrieve the fees (Kirriemuir \& McFarlane 2006, p.11). Third, any aspect of behaviour - including anti- and pro- social behaviour - is a function 
of a complex set of influencers from individual differences to family, social and environmental factors and playing video games is only a part of the big picture (Browne \& Hamilton-Giachritsis, 2005). Therefore, the theoretical explanation of any possible links between playing computer games and increased incidences of anti-social behaviour requires further studies and the current body of literature, compared with what is available for the impacts of viewing violent movies, is limited.

The classical and current theoretical frameworks for the association between playing computer games and heightened anti-social behaviour do not suggest a causal relationship or a direction in the causation although there might be one. As playing violent games might stimulate aggressive behaviour, it is just as likely that children with a primary aggressive personality trait would prefer to play violent video games. This bi-directional relationship between exposure to violent computer games and individual differences (one's predisposition for violence, genetic predisposition, conduct and affective disorder) becomes more sophisticated when family, social and environmental factors are also added to the equation. Therefore, one can say that the effects of media violence will only account for a small proportion of an individual's aggressive behaviour as some systematic meta-analyses have shown.

ICT and Self-regulation. The literature on the HCU contains a body of studies reporting that ICT might facilitate the acquisition and improvement of self-regulated (or independent) learning strategies (Hadwin \& Winne, 2001). The initial understanding of Self-Regulatory Learning (SRL) as a meta-cognitive strategy emphasised on regulation of cognitive processes such as acquiring the crafts of reading, writing and mathematics. SRL is beyond only monitoring of one's own cognitive activities but it encompasses motivational and emotional processes which are important in learning and do need to be regulated. Pintrich's (2000) framework is often cited in studies related to SRL processes and computer-based learning (Winters, Greene \& Costich, 2008). He focused on four areas of SRL processes: a) cognition (e.g. goal-setting, planning, and enacting), b) behaviour (e.g. time management, help-seeking, maintenance and perseverance), c) context (e.g. monitoring of any change in conditions of the task) and motivation (e.g. interest, self-efficacy beliefs).

Having discussed the characteristics and importance of self-regulation strategies in learning, the question posed here is how the new digital technologies can facilitate the acquisition and improvement of these strategies. The answer is shown to be in the affordances of ICT in creating learning environments which scaffold self-regulation strategies (Schunk \& Ertmer, 1999). For instance one obvious affordance of ICT is that it can afford several different representations of information including text, diagrams, graphs etc. (Winters, Greene \& Costich, 2008). Other characteristics which have been applied to most Computer-Based Learning Environments (CBLEs) include, but not restricted to, creation of hypermedia learning environment (i.e. it allows users to select links between these representations or information (Dillon \& Jobst, 2005), ICT affords direct manipulation of the representations (Reiber, 2005), it allows high level of learner control over the pace or mode of learning which at the same time assumes a responsibility for the learner for his learning (Azevedo, 2005), it provides constant feedback on any acts of the learner over the course of learning process (Facer et al., 2001).

The literature contains a body of investigations on the effectiveness of such computer-based tools for enhancing SRL. Although CBLEs are increasingly developed to be used by pupils to learn about conceptually rich domains, studies show that their effectiveness relies heavily on heightened level of users' SRL strategies (Lajoie, 2000). These strategies in turn are a function of individual and contextual processes (Rogoff, 1997). ICTs have important affordances to create learning environments which might foster SRL strategies and other meta-cognitive skills which will ultimately enhance children's performance. These affordances are present in both those environments particularly created for learning a subject or concept and the more generic HCU such as playing games and word-processing. This can be an important characteristic of ICT as self-regulated learners were reported to perform better in school subjects too (Whipp \& Chiarelli, 2004). In addition, SRL strategies are shown to be crucial for developing lifelong learners who have more opportunities for employment when they grow up (Selwyn \& Facer, 2007).

To conclude, studies on the association between $\mathrm{HCU}$ and social/behavioural development, similar to those on school attainment, are limited by the ways in which HCU and behaviour outcomes measures are looked upon and operationalised. Moreover, such research is challenged by the rapidly changing nature of the new technologies. Recent advances in the technology industry have enabled affordances such as technology convergence (e.g. accessing the Internet on different platforms such the home computer, mobile phones and games consoles) which is required to be taken into account while studying children's HCU. The previous findings are mixed because similar to children's school achievement, there is no simple main effect of the ICT on a person's behaviour. There are many situational variables which interact with individual differences to produce people's behavioural outcomes (Mischel, 1973). Moreover, children and young people use the Internet in different ways which in turn lead to having different effects on them. This study takes this body of scholarship further with a longitudinal design to explore the relationships of the HCU and children's social and behaviourial development.

\section{Methodology}

The aim of this study was to investigate the relationship between HCU and children's social/behavioural development. Specifically the two main research questions were:

1.Is a child's social/behaviour development at the end of KS1 and KS2 related to the degree to which that child uses home computers educationally or recreationally?

2. How do effects of HCU and other predictors on social/behavioural development change from KS1 to KS2?

The rationale behind the research questions is the fact that past studies were mostly criticised for narrow conceptualisation of learning attainment through national tests. It is argued that use of technology promotes some forms of learning that are not captured by narrow tests at the end of Key Stages. These learning outcomes - sometimes referred to as 'hidden learning'- are personal attributes like $\mathrm{SRL}$, motivation, independent learning and problem-solving abilities, critical thinking, collaborative learning and higher order skills that are not formally assessed by formal assessments. These qualities might have an ultimate indirect impact on children's performance in these tests (McFarlane et al., 2000). Moreover, there are concerns about possible negative effects of HCU on children's social competence. There have also been studies relating excessive computer use with lower scores on pro-social behaviour and higher levels of anti-social behavior. 


\section{Research Strategy}

In order to address the research aims and questions a quantitative, longitudinal, value-added, large scale, multi-level modelling research strategy was adopted. A value-added strategy refers to the fact that in making statistical models children's prior attainment in Reading and Mathematics, and their prior social/behavioural profile were taken into account. In other words, the effects of HCU on children's outcomes are reported net of their baseline measure. This constitutes a model of progress over time and not merely at any one age. The data for this study came form the Effective Pre-school, Primary and Secondary Education (EPPSE) study which started in 1997 through funds from the Department for Children, Schools and Families (DCSF) (Sylva et. al., 2008) and ended in 2016. The EPPSE study aimed to investigate the effects of pre-school education and care on children's later development. The research team collected a wide range of data on children's developmental profiles, background charac teristics related to the child themselves, their parents, and the pre-schools, primary and secondary schools children attended.

The EPPSE study is designed in a way to enable linking of three sets of data: information about children's attainment and development at different time points, information about children's personal, family and social characteristics, and information about the educational institutions (e.g. type and quality of pre-school settings, effectiveness measures of primary and secondary schools) that children attended.

In order to collect data to address the research project aims, the EPPSE team used various methods of data collection including one-to-one parental interviews, postal questionnaires for parents, questionnaires for pupils on their attitudes to school, teachers' assessment of pupils social/behavioural development, one-to-one standardised assessments of children on their cognitive development and national assessment scores for end of each Key Stage. One area which the EPPSE team has collected data on and has shown it to be a strong predictor of children's cognitive and social development especially during the primary school period is the Home Learning Environment (HLE). This refers to the frequency of broadly educative activities that parents and children do in the home such as reading books, going on educational visits, using home computer and help with homework. HCU is the focal point of interest to this study. The sample of the study was stratified by geographical location and types of pre-school centre. Six Local Authorities (LA) in England in 5 regions (East Anglia, Shire Counties, Inner London, North East and Midlands) were selected strategically so that they cover urban, sub- urban, and rural areas, and a range of social and ethnic backgrounds. From these 6 LAs 141 pres-school centres were then selected through stratified random sampling to include six main types of pre-school provision (playgroups, local authority or voluntary day nurseries, private day nurseries, nursery schools, nursery classes, integrated centres). This means that from each LAs about 20-25 centres were selected in a way that they covered all six main types of pre-school provision. Approximately 20 children from each centre were then randomly selected, thus giving a total of approximately 2800 children. After children were randomly selected from 141 pre-school centres and their families agreed to participate in the study (aged 3 to 4.3 years), children were assessed by a trained researcher in regard to their cognitive and social/behavioural development. This formed the baseline data for children and it was then followed by other cognitive assessments and social/behavioural reports at later stages up to the end of compulsory education. Background information about child, family and HLE characteristics were also obtained first through parental interviews (at entry to the study) followed by parental questionnaires (while children were in Y2, Y6, Y9, Y11).

Reliability of assessment measures were optimised using several strategies. Standardised cognitive tests and social behavioural scales which were tested for reliability in other studies were used at multiple Data on HCU by children on their own and with their parents were obtained through a questionnaire posted to families. The data were collected at two time points: first when children were in KS1 ( $Y 1$ and $\mathrm{Y} 2$ ) and then when they were coming to the end of KS2 (Y5 and Y6). Frequency questions were answered on a 5-point likert scale: 'never', 'hardly ever', 'occasionally', '1 or 2 times a week', 'everyday'. Questions on number of hours on a typical weekday were answered on a 4 point scale from 'less than an hour' to '5+ hours'.

Children's profile of social and behavioural development was created at multiple stages during the EPPSE study. First at entry to study (aged 3 to 4.3 years), children's social/behavioural adjustment was reported by pre-school centre staff using Adaptive Social Behavioural Inventory (ASBI). This assessment formed a baseline against which later progress and development was compared. Table 1 summarises all social/behavioural assessments which were applied to the EPPSE children from entry to study to the end of primary school. For the purpose of this study, children's social/behavioural data at entry to primary school, Year 2 and year 6 are used and data collection procedure for these three time points is explained below.

In order to conceptualise and test relationships between predictors and outcome variables statistical modelling

Table 1. Children's social/behavioural assessments

\begin{tabular}{|c|c|c|c|c|c|c|}
\hline & $\begin{array}{c}\text { Entry to study } \\
\text { (age } 3 \text { to } 4.3 \\
\text { years) }\end{array}$ & $\begin{array}{c}\text { Entry to primary } \\
\text { school (age rising } \\
5 \text { Ys) }\end{array}$ & Year 1(age 6+) & Year 2(age 7+) & Year 5(age 10+) & Year 6(age 11+) \\
\hline $\begin{array}{c}\text { Name of assess- } \\
\text { ment }\end{array}$ & $\begin{array}{l}\text { Adaptive Social } \\
\text { Behavioural } \\
\text { Inventory } \\
\text { (ASBI) (Hogan } \\
\text { et al. 1992) }\end{array}$ & $\begin{array}{l}\text { Child Social } \\
\text { Behavioral Ques- } \\
\text { tionnaire (CSBQ) } \\
\text { which is a revised } \\
\text { and expanded } \\
\text { version of ASBI, } \\
\text { devised by the } \\
\text { EPPSE team }\end{array}$ & $\begin{array}{c}\text { Strength and } \\
\text { Difficulties } \\
\text { Questionnaire } \\
\text { (Goodman 1997) } \\
\text { extended for the } \\
\text { study }\end{array}$ & $\begin{array}{l}\text { Strength and } \\
\text { Difficulties } \\
\text { Questionnaire } \\
\text { (Goodman 1997) } \\
\text { extended for } \\
\text { the study }\end{array}$ & $\begin{array}{c}\text { Strength and } \\
\text { Difficulties } \\
\text { Questionnaire } \\
\text { (Goodman 1997) } \\
\text { extended for the } \\
\text { study }\end{array}$ & $\begin{array}{c}\text { Strength and } \\
\text { Difficulties } \\
\text { Questionnaire } \\
\text { (Goodman 1997) } \\
\text { extended for the } \\
\text { study }\end{array}$ \\
\hline $\begin{array}{l}\text { Assessment } \\
\text { content }\end{array}$ & $\begin{array}{l}\text { Social be- } \\
\text { haviour and } \\
\text { emotional } \\
\text { adjustment }\end{array}$ & $\begin{array}{l}\text { Social and emo- } \\
\text { tional behaviour, } \\
\text { hyperactivity } \\
\text { and settling-in- } \\
\text { to-school }\end{array}$ & $\begin{array}{l}\text { Self-regulation, } \\
\text { hyperactivity, } \\
\text { pro-social and } \\
\text { anti-social } \\
\text { behaviour }\end{array}$ & $\begin{array}{l}\text { Self-regulation, } \\
\text { hyperactivity, } \\
\text { pro-social and } \\
\text { anti-social } \\
\text { behaviour }\end{array}$ & $\begin{array}{l}\text { Self-regulation, } \\
\text { hyperactivity, } \\
\text { pro-social and } \\
\text { anti-social be- } \\
\text { haviour }\end{array}$ & $\begin{array}{l}\text { Self-regulation, } \\
\text { hyperactivity, } \\
\text { pro-social and } \\
\text { anti-social be- } \\
\text { haviour }\end{array}$ \\
\hline
\end{tabular}


was applied. Predictors - or independent/explanatory variables - in this study are HCU and 13 covariates for which effects on outcome variables are studied. Outcome variable - or dependent variable - is social/behavioural outcomes (e.g. self-regulation, pro-social behavior, anti-social behaviour) in this study on which the effects of predictors are studied.

\section{Findings}

Bivariate regression analyses where there was no control of other influencing variables showed that out of four factors extracted for children's social/behavioural profile at the end of KS1, only two of them were statistically associated with children's HCU. 'Self-regulation' was positively associated with children's educational HCU, $r=.06$ (one-tailed), $p<.01$ and 'hyperactivity' was positively associated with children's frequency of HCU for recreational purposes, $r=.04$ (one-tailed), $p<.05$ (Table 2). However, in this preliminary correlational analysis HCU for educational and recreational use accounted for less than $0.5 \%$ of the variance in Self-regulation and Hyperactivity scores. Later multivariate analyses will explore this relationship in greater detail.

It is interesting to see that the direction of relationship between recreational $\mathrm{HCU}$ and the two negative behavioural profiles i.e. 'hyperactivity' and 'anti-social behaviour' were similar. This means that as children's frequency of playing games on home computers increased their rate of being reported as hyperactive and anti-social by teachers increased too. However, this association was not statistically significant.

Table 2. Correlation between HCU and Social/behavioural outcomes in $Y 2$

\begin{tabular}{|c|c|c|c|c|c|}
\hline & & $\begin{array}{l}\text { Self- } \\
\text { regulation }\end{array}$ & $\begin{array}{l}\text { Hyper- } \\
\text { activity }\end{array}$ & $\begin{array}{l}\text { Pro- } \\
\text { social }\end{array}$ & $\begin{array}{l}\text { Anti- } \\
\text { social }\end{array}$ \\
\hline \multirow{2}{*}{$\begin{array}{l}\text { HCU for } \\
\text { educational } \\
\text { purposes } \\
\text { (HCUfE) }\end{array}$} & $\begin{array}{l}\text { Pearson } \\
\text { correlation }\end{array}$ & .06 & -.007 & .02 & -.02 \\
\hline & $\begin{array}{c}\text { Sig. } \\
\text { (1-tailed) }\end{array}$ & $<.01$ & ns & ns & ns \\
\hline \multirow{2}{*}{$\begin{array}{l}\text { HCU for } \\
\text { recreational } \\
\text { purposes } \\
\text { (HCUfR) }\end{array}$} & $\begin{array}{l}\text { Pearson } \\
\text { correlation }\end{array}$ & .002 & .04 & -.03 & .01 \\
\hline & $\begin{array}{c}\text { Sig. } \\
\text { (1-tailed) }\end{array}$ & ns & $<.05$ & ns & ns \\
\hline
\end{tabular}

Therefore on the basis of having a significant association with variables of primary interest to this study (i.e. HCUfE and HCUfR) it was decided that further analyses would focus on the scales of 'self-regulation' and 'hyperactivity'. Groups of children showed different patterns of social/behavioural profile at the end of KS1.

Table 3. Two social/behavioural outcomes by groups of children

\begin{tabular}{cccccccc}
\hline $\begin{array}{c}\text { Y 2 Social / } \\
\text { behavioural }\end{array}$ & \multicolumn{3}{c}{ Self-regulation } & \multicolumn{3}{c}{ Hyperactivity } \\
\hline \multirow{3}{*}{ Genderyyyyyyy} & & $n$ & mean & sd & $n$ & mean & sd \\
\cline { 2 - 9 } & Male & 873 & 2.33 & 0.51 & 875 & 1.75 & 0.44 \\
\cline { 2 - 9 } & Female & 856 & 2.45 & 0.45 & 855 & 1.56 & 0.37 \\
\cline { 2 - 9 } & Total & 1729 & 2.39 & 0.48 & 1730 & 1.66 & 0.42 \\
\hline \multirow{3}{*}{ FSM } & Yes & 273 & 2.21 & 0.49 & 273 & 1.79 & 0.44 \\
\cline { 2 - 9 } & No & 1439 & 2.42 & 0.48 & 1440 & 1.63 & 0.41 \\
\cline { 2 - 8 } & Total & 1729 & 2.39 & 0.48 & 1730 & 1.66 & 0.42 \\
\hline
\end{tabular}

As shown in Table 3 the mean scores for girls are somewhat higher for Self-regulation and lower for Hyperactivity. Free School Meals (FSM) used as an indicator of low income showed that children rated as eligible for FSMs had relatively poorer behaviour ratings than other children. Results show a linear relationship between mothers' highest level of education and their Self-regulation scores in Y2 as rated by their class teachers. Results show a negative linear relationship between children's HLE and their Hyperactivity scores.

Table 4 summarises the associations between all covariates 4 and Self-regulation, Hyperactivity. The table shows that Self-regulation had a significant correlation with all covariates except 'number of siblings'. HLE, family's highest Socio-Economic Status (SES) and mother's education had the strongest linear link with the extent to which children were reported as 'self-regulated' by their class teachers. Hyperactivity was also significantly related to all covariates except 'ethnicity' and 'EAL'. The gender of the child had the strongest link indicating that boys were reported to be much more hyperactive than girls. Father's level of education was also significantly and negatively associated with hyperactivity scores of children, indicating that children whose fathers were less educated were reported as being more hyperactive by their teachers at the end of Year 2 .

Table 4. Pearson correlations between covariates and two Social/behavioural outcomes

\begin{tabular}{|c|c|c|c|}
\hline & $\begin{array}{c}\text { Self- } \\
\text { regulation Y2 }\end{array}$ & $\begin{array}{c}\text { Hyperactivity } \\
\text { Y2 }\end{array}$ & \\
\hline Birth weight & $.09 * *$ & $-.08 * *$ & \multirow{7}{*}{$\begin{array}{l}\text { Individual } \\
\text { Block }\end{array}$} \\
\hline Gender & $.12^{\star \star}$ & $-.22 * \star$ & \\
\hline Ethnicity & $-.05 *$ & ns & \\
\hline EAL & $.11 * *$ & ns & \\
\hline $\begin{array}{l}\text { Developmental } \\
\text { Problems }\end{array}$ & $.11 * *$ & $-.07 * *$ & \\
\hline Health Problems & $.05 *$ & $-.04 *$ & \\
\hline $\begin{array}{l}\text { Behaviour } \\
\text { Problems }\end{array}$ & $.11 * *$ & $-.13 * *$ & \\
\hline Mother's education & $.21 * \star$ & $-.14^{\star \star}$ & \multirow{5}{*}{$\begin{array}{l}\text { Family } \\
\text { Block }\end{array}$} \\
\hline Father's education & $.18 * *$ & $-.18 * *$ & \\
\hline Family SES & $-.22 * \star$ & $.15^{\star *}$ & \\
\hline FSM & $.15^{\star \star}$ & $-.14^{\star *}$ & \\
\hline Number of siblings & ns & $-.06 * *$ & \\
\hline HLE & $.23 * \star$ & $-.18 * *$ & HLE Block \\
\hline
\end{tabular}

In order to see the progress that children made in their social/behavioural development from a prior point to their current status at the end of KS1 (aged 7), children's social/ behavioural profile at entry to primary school was considered as their baseline measure. At entry to primary school, teachers completed the Child Social Behaviour Questionnaire (CSBQ), an instrument developed by the EPPSE team from ASBI (Hogan et. al. 1992). The instrument had 45 items rated on a 5-point scale ( $1=$ rarely $/$ never to $5=$ almost always). Principal Components Analysis extracted 6 underlying factors (Appendix E). Each child's score for each of the factors was calculated by averaging the ratings given by teachers for the questions that formed that factor. In order to see the consistency of responses Cronbach Alpha was used. As a rule of thumb values above 0.60 were considered appropriate. In order to select the proper base line measures for Self-regulation and Hyperactivity outcomes, the correlations between all 6 factors and these two outcome measures were studied. As shown in the Table 5 for Self-regulation and Hyperactivity, the measure of Independence and Concentration (I\&C) at the start of primary school was the strongest predictor. Note that the link between Hyperactivity and I\&C was negative meaning that children rated more highly in terms of Independence and Concentration at entry to primary school, were less likely to show raised scores for Hyperactivity later, at the 
end of $Y 2$. On the basis of this, I\&C factor at entry to primary school was considered as the baseline measure for both Hyperactivity and Self-regulation at end of KS1.

Table 5. Correlation between entry to school measures and the two social/behavioural outcomes in Y2

\begin{tabular}{|c|c|c|c|}
\hline & & $\begin{array}{c}\text { Self-regulation } \\
\text { Y2 }\end{array}$ & $\begin{array}{c}\text { Hyperactivi- } \\
\text { ty } \mathrm{Y} 2\end{array}$ \\
\hline \multirow{2}{*}{$\begin{array}{l}\text { Independ- } \\
\text { ence \& } \\
\text { Concentration }\end{array}$} & $\begin{array}{l}\text { Pearson } \\
\text { correlation }\end{array}$ & .40 & -.42 \\
\hline & Sig. (1-tailed) & $<.01$ & $<.01$ \\
\hline \multirow{2}{*}{$\begin{array}{l}\text { Co-operation } \\
\& \text { Conformity }\end{array}$} & $\begin{array}{l}\text { Pearson } \\
\text { correlation }\end{array}$ & .31 & -.38 \\
\hline & Sig. (1-tailed) & $<.01$ & $<.01$ \\
\hline \multirow{2}{*}{$\begin{array}{l}\text { Peer Socia- } \\
\text { bility }\end{array}$} & $\begin{array}{l}\text { Pearson } \\
\text { correlation }\end{array}$ & .27 & -.08 \\
\hline & Sig. (1-tailed) & $<.01$ & $<.01$ \\
\hline \multirow{2}{*}{$\begin{array}{l}\text { Anti-social/ } \\
\text { worried }\end{array}$} & $\begin{array}{l}\text { Pearson } \\
\text { correlation }\end{array}$ & -.15 & .30 \\
\hline & Sig. (1-tailed) & $<.01$ & $<.01$ \\
\hline \multirow{2}{*}{$\begin{array}{l}\text { Empathy \& } \\
\text { pro-social }\end{array}$} & $\begin{array}{l}\text { Pearson } \\
\text { correlation }\end{array}$ & .31 & -.26 \\
\hline & Sig. (1-tailed) & $<.01$ & $<.01$ \\
\hline \multirow{2}{*}{ Confidence } & $\begin{array}{l}\text { Pearson } \\
\text { correlation }\end{array}$ & .30 & -.14 \\
\hline & Sig. (1-tailed) & $<.01$ & $<.01$ \\
\hline
\end{tabular}

Association between HCU and children's social/behavioural development

Table 6 colour-codes the relevant covariates for each outcome variable in KS1. Yellow cells highlight those variables selected to be included in the models. Blue cells highlight covariates that had a significant association with relevant outcome variable at least at $95 \% \mathrm{Cl}$ but were not included in models because the association was weak, past studies did not use them frequently or another variable indicating similar factor was selected.

Table 6. Covariate analysis and selection

\begin{tabular}{|c|c|c|c|}
\hline & \multicolumn{2}{|c|}{ Social/behavioural outcomes } & \\
\hline & $\begin{array}{l}\text { Self-regula- } \\
\text { tion Y2 }\end{array}$ & $\begin{array}{l}\text { Hyperactivi- } \\
\text { ty } Y 2\end{array}$ & \\
\hline Birth weight & & & \multirow{7}{*}{$\begin{array}{l}\text { Individual } \\
\text { Block }\end{array}$} \\
\hline Gender & & & \\
\hline Ethnicity & & & \\
\hline EAL & & & \\
\hline $\begin{array}{l}\text { Developmental } \\
\text { Problems }\end{array}$ & & & \\
\hline $\begin{array}{l}\text { Health Prob- } \\
\text { lems }\end{array}$ & & & \\
\hline $\begin{array}{l}\text { Behaviour } \\
\text { Problems }\end{array}$ & & & \\
\hline $\begin{array}{l}\text { Mother's edu- } \\
\text { cation }\end{array}$ & & & \multirow{5}{*}{$\begin{array}{l}\text { Family } \\
\text { Block }\end{array}$} \\
\hline $\begin{array}{l}\text { Father's edu- } \\
\text { cation }\end{array}$ & & & \\
\hline Family SES & & & \\
\hline FSM & & & \\
\hline $\begin{array}{l}\text { Number of } \\
\text { siblings }\end{array}$ & & & \\
\hline HLE & & & HLE Block \\
\hline
\end{tabular}

\section{Findings for Self-regulation in Y2}

There was data for 1729 children on their Self-regulation scores. The distribution did not fit a normal distribution and it was skewed to the right (skew=-.61). For the same reasons discussed for Reading and Mathematics, parametric test of linear regression was used to model the data. Table 7 reports standardised regression coefficients $(\beta)$ of significant predictors for each model as well as the amount of variance explained by each model. As shown in the table the amount of variance explained by each model increased as more predictors were added into the model. Constant for each model is also reported. The level of educational and recreational uses of home computers in KS1 was not associated with their Self-regulation scores in Y2 after controlling for their prior Independence and Concentration profile at entry to primary school, individual, family and HLE characteristics. The association between HCU for educational purposes and Self-regulation was significant and positively related only in bivariate analysis where there was no control of any other influencing variables, $(\beta=.08, p<.05)$. Recreational HCU, as shown in Section 6.2.2.1, showed no significant link with children's Self-regulation scores.

Children's prior profile in Independence and Concentration at entry to primary school was the strongest predictor of their Self-regulation scores at the end of $\mathrm{Y} 2$ in all models. This was followed by children's early-years HLE scores, family SES, gender, reported early-years behaviour problems, mother's level of education and family economic status as measured by eligibility for Free School Meals. Girls, those who did not have any early-years behaviour problems, children from more advantaged families (higher SES, educated parents and not eligible for FSMs) with richer HLE showed higher scores of Self-regulation after controlling for their baseline Independence and Concentration profile at entry to primary school.

\section{Findings for Hyperactivity Y2}

The second measure of social/behaviour development which showed a significant relationship with one measure of HCU in bivariate analyses was Hyperactivity. There was a weak but significant association of $r=.04, p<.05$ between HCUfR and Hyperactivity indicating that children who played more on home computers showed more Hyperactivity related behaviour as reported by their teacher. It is important to remind that lower scores on Hyperactivity scale were considered a better behaviour rather than higher scores. There are data on Hyperactivity profile of 1730 children when they were 6/7 at the end of KS1. The distribution was positively skewed (skew $=.93$ ) indicating that a great proportion of children were not reported by their Y2 teachers as being Hyperactive. Due to similar reasons discussed for Reading scores, parametric test of linear regression was used to make statistical model. Table 8 reports standardised regression coefficients $(\beta)$ of significant predictors for each model as well as the amount of variance explained by each model.

The strongest predictor of Hyperactivity in Y2 was children's reported profile on Independence and Concentration scale at entry to primary school. Children who were reported to be more independent at age rising 5 at entry to primary school were reported by their Y2 teachers to be less Hyperactive. Boys were reported to be more Hyperactive after controlling for their other background characteristics like family SES. Children from poorer family as assessed by eligibility for FSMs were also reported be more Hyperactive compared to their peers who were not eligible for FSMs after taking into account other variables. Children who were reported by their parents during parental interviews to have behaviour problems at early 
Table 7. Hierarchical linear regression results for Self-regulation Y2

\begin{tabular}{|c|c|c|c|c|c|}
\hline & $\begin{array}{l}\text { Model } 1 \\
\text { (HCU only) }\end{array}$ & $\begin{array}{c}\text { Model2 } \\
\text { (Baseline measure) }\end{array}$ & $\begin{array}{c}\text { Model } 3 \\
\text { (Individual block) }\end{array}$ & $\begin{array}{c}\text { Model } 4 \\
\text { (Family block) }\end{array}$ & $\begin{array}{l}\text { Model } 5 \\
\text { (HLE block) }\end{array}$ \\
\hline HLE & & & & & $.09 * *$ \\
\hline SES & & & & $-.08 * \star$ & $-.07 *$ \\
\hline FSM & & & & $.05^{*}$ & $.05 *$ \\
\hline EAL & & & $.08^{* *}$ & $.05^{*}$ & ns \\
\hline Behaviour problems & & & $.07 * \star$ & $.05 *$ & $.06 *$ \\
\hline Independence \& Concentration at entry to school & & .41 ** & $.38 * \star$ & $.35 * \star$ & $.34 * \star$ \\
\hline HCU for Education & $.08^{*}$ & ns & ns & ns & ns \\
\hline
\end{tabular}

* Significant at $p=$ or $<.05 ; * *$ Significant at $p=$ or <.01; \# just failed to reach significance level at $p=.05$; $n$ s: non-significant

Table 8. Hierarchical linear regression results for Hyperactivity Y2

\begin{tabular}{|c|c|c|c|c|c|}
\hline & $\begin{array}{l}\text { Model } 1 \\
\text { (HCU only) }\end{array}$ & $\begin{array}{c}\text { Model2 } \\
\text { (Baseline measure) }\end{array}$ & $\begin{array}{c}\text { Model } 3 \\
\text { (Individual block) }\end{array}$ & $\begin{array}{c}\text { Model } 4 \\
\text { (Family block) }\end{array}$ & $\begin{array}{c}\text { Model } 5 \\
\text { (HLE block) }\end{array}$ \\
\hline HLE & & & & & $-.04 \mathrm{~ns}$ \\
\hline SES & & & & $.04 \mathrm{~ns}$ & $.04 \mathrm{~ns}$ \\
\hline FSM & & & & $-.07 * \star$ & $-.07 * \star$ \\
\hline EAL & & & $-.08 * *$ & $-.07 * \star$ & $-.07 * \star$ \\
\hline Independence \& Concentration at entry to school & & $-.44 * *$ & $-.41 * *$ & $-.39 * *$ & $-.38^{* *}$ \\
\hline HCU for Education & $-.05 n s$ & $.007 n s$ & $.03 n s$ & $.05 \#$ & $.06 *$ \\
\hline HCU for Recreation & $.07 *$ & $.03 n s$ & $-.008 \mathrm{~ns}$ & $-.03 n s$ & $-.02 \mathrm{~ns}$ \\
\hline
\end{tabular}

* Significant at $p=$ or $<.05 ; * *$ Significant at $p=$ or $<.01$; \# just failed to reach significance level at $p=.05$; $n$ s: non-significant

Table 9. Comparing HCU effect sizes on KS1 outcome measures

\begin{tabular}{|c|c|c|c|c|c|c|c|}
\hline \multicolumn{2}{|c|}{$\begin{array}{l}\text { HCU and KS1 } \\
\text { Outcomes }\end{array}$} & Baseline measure and Covariates & $\begin{array}{c}R^{2}(\text { for } \\
\text { Model 5) }\end{array}$ & \multicolumn{2}{|c|}{ Model 2} & \multicolumn{2}{|c|}{ Model 5} \\
\hline \multirow{2}{*}{ 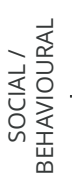 } & Self-regulation & $\begin{array}{l}\text { Independence \&Concentration, } \\
\text { gender, EAL, behaviour problems, } \\
\text { mother's education, SES, FSM and HLE }\end{array}$ & .21 & ns & ns & ns & ns \\
\hline & Hyper-activity & $\begin{array}{l}\text { Independence \&Concentration, gen- } \\
\text { der, behaviour problems, mother's } \\
\text { education, SES, FSM and HLE }\end{array}$ & .23 & ns & ns & $.06 *$ & ns \\
\hline
\end{tabular}

years of life scored higher on Hyperactivity scales in Y2 after the effects of other variables were partialled out.

Table 9 compares effect sizes (or standardised $\beta$ Coefficients) of HCU for educational (HCUfE) and recreational (HCUfR) purposes on two social/behaviour outcomes (Self-regulation and Hyperactivity) at the end of KS1 using hierarchical linear regression. Surprisingly educational HCU showed a statistically significant impact on Hyperactivity of children. Frequent users of home computers for educational purposes were reported to be more hyperactive after controlling for all other things. Recreational HCU was not a significant predictor of Hyperactivity and Self-regulation. Table 9 also shows that family characteristics (such as SES, mother's qualification and economic status) and parenting (i.e. HLE) are the ones which made the effects of HCU on children's development non-significant.

\section{Longitudinal effects}

An extended version of Strength and Difficulties Questionnaire (Goodman 1997) was completed by Y6 teachers for every child. The questionnaire captured social adjustment of children and their behaviour profile at age 11. Principal Component Analysis and Confirmatory Factor Analysis were applied to summarise the questionnaire items into underlying dimensions. Four main factors were extracted: Self-regulation, Hyperactivity, Pro-social and Anti-social behaviour. Table 10 shows the four factors, the corresponding items and the factor loadings. Factor scores for each child were then calculated by averaging the rating given by the teacher for the questions that form each factor. A measure of internal consistency between the items of a given factor, Cronbach Alpha, was also used to confirm that teachers' responses to related questions were all consistent.

\section{Self-regulation in Year 6}

Data on the self-regulation profile of 1791 children were available in the sample. Table 11 reports that educational HCU showed a significant association with raised scores in Self-regulation in Year 6 after controlling for their prior self-regulatory profile in Year 2 and their individual child 
Table 10. Factor loadings for Y6 Social/behavioural outcomes

\begin{tabular}{|c|c|c|c|c|}
\hline Items & $\begin{array}{l}\text { Factor } 1 \text { Self- } \\
\text { regulation }\end{array}$ & $\begin{array}{c}\text { Factor } 2 \\
\text { Hyper-activity }\end{array}$ & $\begin{array}{l}\text { Factor } 3 \\
\text { Pro-social } \\
\text { behaviour }\end{array}$ & $\begin{array}{c}\text { Factor } 4 \\
\text { Anti-social } \\
\text { Behaviour }\end{array}$ \\
\hline Likes to work things out for self; seeks help rarely & .56 & & & \\
\hline Does not need much help with tasks & .65 & & & \\
\hline Chooses activities on their own & .59 & & & \\
\hline Persists in the face of difficult tasks & .45 & & & \\
\hline Can move on to a new activity after finishing a task & .66 & & & \\
\hline Open and direct about what she/he wants & .47 & & & \\
\hline Confident with others & .65 & & & \\
\hline Shows leadership in group work & .73 & & & \\
\hline Can take responsibility for a task & .71 & & & \\
\hline Considerate of other people's feelings & & & .65 & \\
\hline Shares readily with other children (treats, toys, etc.) & & & .52 & \\
\hline Helpful if someone is hurt, upset or feeling ill & & & .63 & \\
\hline Kind to younger children & & & .43 & \\
\hline Often volunteers to help others (teachers, other children) & & & .49 & \\
\hline Offers to help others having difficulties with a task & & & .51 & \\
\hline Sympathetic to others if they are upset & & & .60 & \\
\hline Apologises spontaneously & & & .48 & \\
\hline Restless, overactive, cannot stay still for long & & .65 & & \\
\hline Constantly fidgeting or squirming & & .56 & & \\
\hline Easily distracted, concentration wanders & & .49 & & \\
\hline Thinks things out before acting & & -.47 & & \\
\hline Sees tasks through to the end, good attention span & & -.54 & & \\
\hline Quickly loses interest in what she/he is doing & & .60 & & \\
\hline Gets over excited & & .64 & & \\
\hline Easily frustrated & & .71 & & \\
\hline Impulsive, acts without thinking & & .70 & & \\
\hline Can behave appropriately during less structured sessions & & -.53 & & \\
\hline Fails to pay attention & & .65 & & \\
\hline Makes careless mistakes & & .58 & & \\
\hline Often fights with other children or bullies & & & & .65 \\
\hline Often lies or cheats & & & & .48 \\
\hline Steals from home, school or elsewhere & & & & .56 \\
\hline Vandalises property or destroys things & & & & .45 \\
\hline Shows inappropriate sexual behavior toward others & & & & .47 \\
\hline Has been in trouble with the law & & & & .36 \\
\hline $\begin{array}{l}\text { characteristics. However after the effects of family and } \\
\text { HLE were partialled out, the association became non-sig- } \\
\text { nificant. The strongest predictors of children's Self-regu- } \\
\text { lation profile in Year } 6 \text { were their social adjustment score } \\
\text { in Year 2, their mothers' highest level of education, the as- } \\
\text { pect of HLE related to child's independent learning activ- } \\
\text { ities in the home, family SES and gender (favouring girls). } \\
\text { Self-regulation in Year } 6 \\
\text { Data on the self-regulation profile of } 1791 \text { children were } \\
\text { available in the sample. Table } 11 \text { reports that educational } \\
\text { HCU showed a significant association with raised scores } \\
\text { in Self-regulation in Year } 6 \text { after controlling for their prior } \\
\text { self-regulatory profile in Year } 2 \text { and their individual child } \\
\text { characteristics. However after the effects of family and } \\
\text { HLE were partialled out, the association became non-sig- } \\
\text { nificant. The strongest predictors of children's Self-regu- } \\
\text { lation profile in Year } 6 \text { were their social adjustment score } \\
\text { in Year 2, their mothers' highest level of education, the } \\
\text { aspect of HLE related to child's independent learning ac- }\end{array}$ & \multicolumn{4}{|c|}{$\begin{array}{l}\text { tivities in the home, family SES and gender (favouring girls) } \\
\text { Pro-social behaviour in Year } 6 \\
\text { Data were available on the aspect of social/behavioural } \\
\text { profile related to Pro-social behaviour for } 1791 \text { children. } \\
\text { Table } 12 \text { shows significant predictors of children's Pro-so- } \\
\text { cial behaviour at the end of KS2. Bivariate analyses showed } \\
\text { a significant and positive association between Pro-social } \\
\text { behaviour of children in Y6 and their educational HCU } \\
\text { while a significant, stronger but negative association with } \\
\text { recreational HCU. HCU to play games remained a signifi- } \\
\text { cant predictor of children's' Pro-social behaviour after con- } \\
\text { trolling for their prior pro-social profile in Year } 2 \text { and their } \\
\text { demographic characteristics. It indicated that the more } \\
\text { children played on computers, the less they were reported } \\
\text { to have Pro-social behaviour in the classroom after con- } \\
\text { trolling for all other covariates. The strongest predictors of } \\
\text { pro-social behaviour were children's baseline measures in } \\
\text { Year 2, gender (favouring girls) and their HLE in KS2. }\end{array}$} \\
\hline
\end{tabular}


Table 11. Significant predictors of Self-regulation Y 6

\begin{tabular}{|c|c|c|c|c|c|}
\hline & $\begin{array}{l}\text { Model } 1 \\
\text { (HCU only) }\end{array}$ & $\begin{array}{c}\text { Model2 } \\
\text { (+Baseline measure) }\end{array}$ & $\begin{array}{c}\text { Model } 3 \\
\text { (+Individual block) }\end{array}$ & $\begin{array}{c}\text { Model } 4 \\
\text { (+Family block) }\end{array}$ & $\begin{array}{c}\text { Model } 5 \\
(+ \text { HLE block })\end{array}$ \\
\hline KS2 HLE Child's independent learning activities & & & & & $.08^{* *}$ \\
\hline SES & & & & $-.06 *$ & $-.06 *$ \\
\hline Gender & & & $.07 * \star$ & $.08^{\star \star}$ & $.07 * *$ \\
\hline HCU for Education & $.11 * \star$ & $.08^{* \star}$ & $.06 *$ & ns & ns \\
\hline HCU for Recreation & $-.08^{* \star}$ & $-.04 \mathrm{~ns}$ & $-.01 \mathrm{~ns}$ & ns & ns \\
\hline Variance explained & .01 & .28 & .29 & .32 & .33 \\
\hline Constant & .02 & .006 & .005 & .002 & .000 \\
\hline
\end{tabular}

Table 12. Significant predictors of Pro-social behaviour Y6

\begin{tabular}{|c|c|c|c|c|c|}
\hline & $\begin{array}{c}\text { Model } 1 \\
\text { (HCU only) }\end{array}$ & $\begin{array}{c}\text { Model2 } \\
\text { (+Baseline measure) }\end{array}$ & $\begin{array}{c}\text { Model } 3 \\
\text { (+Individual block) }\end{array}$ & $\begin{array}{c}\text { Model } 4 \\
\text { (+Family block) }\end{array}$ & $\begin{array}{c}\text { Model } 5 \\
(+ \text { HLE block })\end{array}$ \\
\hline KS2 HLE Child's independent learning activities & & & & & $.07 *$ \\
\hline Gender & & & $.20 * *$ & $.20 * *$ & $.18^{* *}$ \\
\hline Ethnicity & & & $-.05 *$ & ns & ns \\
\hline HCU for Education & $.10^{* *}$ & $.07 *$ & $.02 \mathrm{~ns}$ & ns & ns \\
\hline HCU for Recreation & $-.16^{\star \star}$ & $-.11 * *$ & $-.05 *$ & $-.05 *$ & $-.05 *$ \\
\hline Variance explained & .02 & .17 & .21 & .22 & .23 \\
\hline Constant & .02 & .02 & .02 & .01 & .01 \\
\hline
\end{tabular}

* Significant at $p=$ or $<.05 ; * *$ Significant at $p=$ or $<.01$; \# just failed to reach significance level at $p=.05$; $n$ s: non-significant

Table 13. Significant predictors of Hyperactivity in Y6

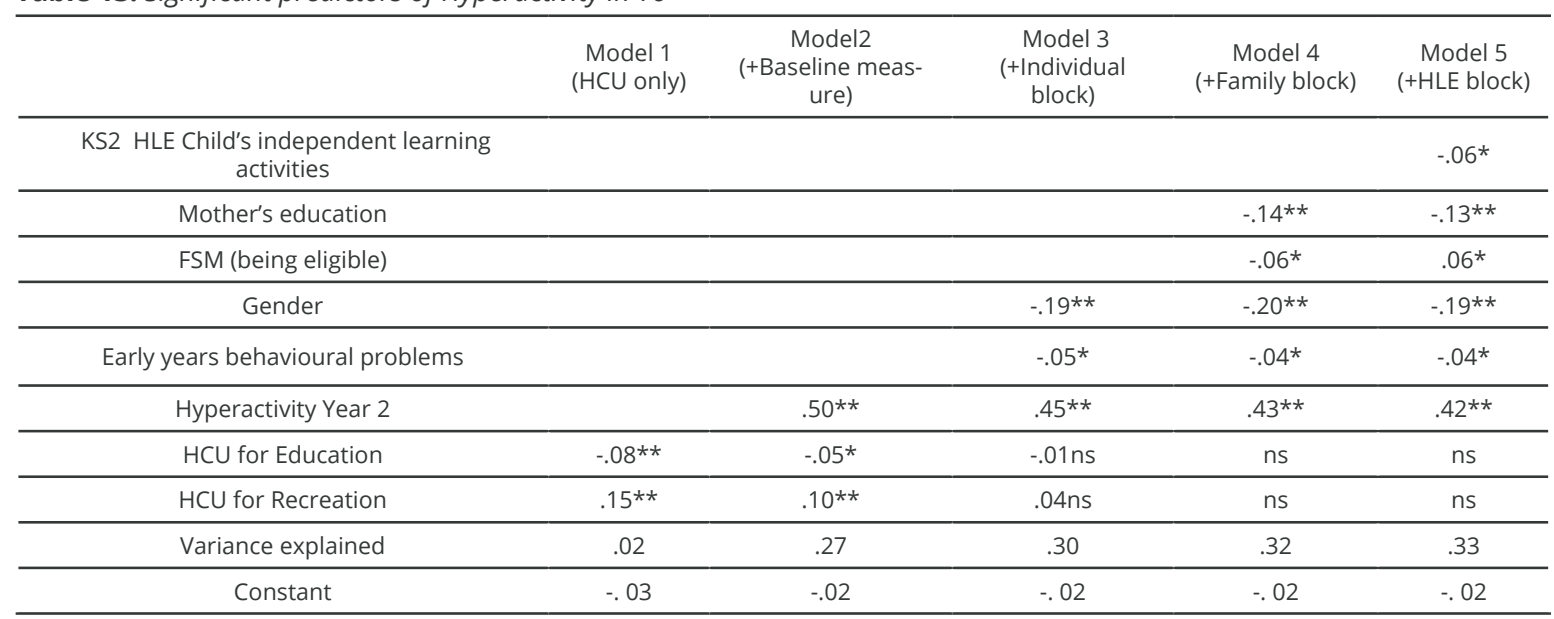

* Significant at $p=$ or <.05; ** Significant at $p=$ or <.01; \# just failed to reach significance level at $p=.05$; ns: non-significant

Hyperactivity in Year 6

Data on the Hyperactivity profile of 1792 children were available in the sample. Bivariate analyses showed that educational HCU had a negative and significant association with children's hyperactivity scores assessed by their Year 6 class teachers (Table 13). Recreational HCU, by contrast, showed a positive association with hyperactivity scores indicating that children who played games more frequently on HCU were more likely to be rated as hyperactive by their class teachers. This relationship pattern remained the same after children's prior hyperactivity profile in Year 2 was also taken into account. However, after the effects of individual child, family and HLE characteristics were partialled out, these significant associations faded away. The strongest predictors of children's hyperactivity were their prior profile in the same social/behavioural domain in Year 2 followed by gender (boys were more likely to be reported as hyperactive), their mother's level of education (children from less educated mothers had higher scores in hyperactivity), eligibility for Free School Meals (FSM) as an indicator of family poverty, having behavioural problems during pre-schools as reported by parents and HLE (negatively associated with child's independent learning activities in the home).

\section{Anti-social behaviour in Year 6}

Data on the Anti-social behaviour of 1790 children were reported by their class teachers in Y6. Table 14 shows that in initial bivariate analyses recreational HCU was significantly associated with raised scores in anti-social behaviour as assessed by class teachers in Year 6 . By contrast levels of educational HCU were negatively associated with 
Table 13. Significant predictors of Hyperactivity in Y6

\begin{tabular}{|c|c|c|c|c|c|}
\hline & $\begin{array}{l}\text { Model } 1 \\
\text { (HCU only) }\end{array}$ & $\begin{array}{c}\text { Model2 } \\
\text { (+Baseline meas- } \\
\text { ure) }\end{array}$ & $\begin{array}{c}\text { Model } 3 \\
\text { (+Individual } \\
\text { block) }\end{array}$ & $\begin{array}{c}\text { Model } 4 \\
\text { (+Family block) }\end{array}$ & $\begin{array}{c}\text { Model } 5 \\
\text { (+HLE block) }\end{array}$ \\
\hline $\begin{array}{l}\text { KS2 HLE Child's independent learning } \\
\text { activities }\end{array}$ & & & & & $-.13^{\star \star}$ \\
\hline Mother's education & & & & $-.07 *$ & $-.06 *$ \\
\hline FSM (being eligible) & & & & $-.08^{* \star}$ & $.08 * *$ \\
\hline Gender & & & $-.11 \star \star$ & $-.12 \star \star$ & $-.08 * \star$ \\
\hline Anti-social behaviour Year 2 & & $.37 * *$ & $.36 * *$ & $.34 * *$ & $.33^{* *}$ \\
\hline HCU for Education & $-.07 *$ & $-.04 \mathrm{~ns}$ & $-.02 \mathrm{~ns}$ & ns & ns \\
\hline HCU for Recreation & $.07 *$ & $.08^{* \star}$ & $.04 \mathrm{~ns}$ & ns & ns \\
\hline Variance explained & .005 & .14 & .16 & .17 & .19 \\
\hline Constant & -.04 & -.03 & -.03 & -.03 & -.03 \\
\hline
\end{tabular}

incidents of children being reported to have anti-social behaviour. This relationship was consistent for HCU to play games even after controlling for children's prior anti-social behaviour profile in Year 2. However, after effects of individual, family and HLE characteristics were taken into account the linear significant association between scores in anti-social behaviour and both types of HCU disappeared.

\section{Discussions and Conclusion}

For social/behavioural development in primary school children's prior social/behaviour profiles at age $3+$ and 7 were the strongest predictors of their social/behavioural development at age 7 and 11 respectively. There were also marked gender differences on all measures of social/ behavioural development. Girls were rated by their teachers as displaying more 'self-regulation' and 'pro-social' behaviour than boys, whereas boys were rated more highly on 'hyperactivity' and 'anti-social' behaviour than boys. Comparing the effect sizes across the two key stages show that gender effects increase on all measures of social/ behavioural development as children grow up. Children who were reported by their parents to have behavioural problems at pre-school age showed lower self-regulation behaviour and more hyper-active behaviour at age 7 and 11 compared to those who had no early years behavioural problems. In terms of effect sizes, they reduced as children grew up from Year 2 to Year 6 . Family socio-economic status was significantly associated with raised reported levels of self-regulation and the strength of the effect decreased as children grew older. Mother's level of education was a significant predictor for all measures of social/behavioural development except 'pro-social' behaviour after controlling for the effects of other factors in primary school. Higher mother's educational levels were associated with higher teacher rated self-regulation and lower levels of hyperactivity and anti-social behaviour. The magnitude of effect sizes related to mother's educational level increased in primary school period. Eligibility for Free School Meals as a proxy for family poverty showed a negative association with self-regulation and a positive association with hyperactivity and anti-social behaviour. This means that poorer children were reported by their teachers to show lower levels of self-regulation in Year 2 while they showed higher levels of hyperactivity in Years 2 and 6 and higher levels of anti-social behaviour in Year 6 . The comparison can be made for only hyperactivity for which FSM was significant for both Years 2 and 6 . It showed a slight decrease of .01 from Year 2 to Year 6. Finally HLE showed a positive linear association with teacher rated raised scores of self-regulation and pro-social behaviour and a negative association with hyperactivity and anti-social behaviour. Those children who had higher scores in early years HLE reported by their teachers to be more self-regulated in
Year 2. And those children who were reported by their parents to have more independent learning activities in the home in KS2 were also reported to show higher levels of self-regulation and pro-social behaviour and lower levels of hyperactivity and anti-social behaviour in Year 6 .

Data from the current study were congruent with the first group of studies only in regard to the negative contribution of using home computers to recreate (i.e. playing games) during KS2 to children's level of pro-social behaviour in Year 6. This negative influence is the net effect of HCU for recreational purposes net of children's prior profile in Year 2 and the contribution of child individual, family and HLE characteristics. The measure of pro-social behaviour in the present study represents child's behaviour in Year 6 such as 'considerate of other people's feelings', 'kind to younger children', 'offers to help others having difficulties with a task'. Reviewing the emerging trends in the study revealed that children's HCU to play games had a steep increase from age $6 / 7$ to age $10 / 11$ and this was relevant mostly to boys. At the same time, boys scored lower than girls in measures of pro-social behaviour in both Year 2 and Year 6 . One might infer that the negative contribution of $\mathrm{HCU}$ for recreational purposes to pro-social behaviour is related to the increased level of games playing as children grew older because the statistical model controlled for gender effects. The mechanism why and how games playing might cause decline of children's social/behaviour cannot be deduced from the data in this thesis. However, some theoretical models maintain that extensive games playing - particularly games which contain an aggressive theme - might desensitise children to their peers' suffering (Anderson \& Bushman, 2001) as this principle is now included in training military forces to make them indifferent to their target's suffering.

One further finding from the current study was the significant association between educational use of home computers during KS1 and raised level of children's hyperactivity in Year 2 as reported by their teachers. This finding is surprising to the researcher and cannot be explained by the contextual literature in the field. Therefore, it requires a further study to understand this association. It is worth remembering that in KS1 the educational HCU was only reported about parents' HCU with children and the frequency of use was relatively low.

Two other social/behavioural outcomes - anti-social behaviour and self-regulation - were not associated with children's HCU over and beyond what can be predicted based on children's prior social/behavioural profile and their demographic background characteristics. These results are particularly important as there is a public concern over the negative influence of games playing 
on children's increased level of aggression. The findings here are compatible with some studies such as Fleming \& Rickwood (2001) which reported no association between moderate uses of computers for recreation and anti-social behaviour. Frequency of recreational HCU among the sample of the present study, therefore, should be considered as moderate rather than extensive. One further explanation for the dissociation between $\mathrm{HCU}$ and measures of anti-social behaviour and self-regulation might be the existence of relatively more important factors in the equation such as family and HLE characteristics. The step-wise inclusion of these factors also confirms this explanation as the inclusion of family SES, mother's level of education and HLE characteristics made the initial significant association non-significant. Family contribution might be in the form of at-home rules and regulation about the time and types of $\mathrm{HCU}$, making $\mathrm{HCU}$ a shared family practice rather than an individual experience (Holloway \& Valentine, 2003). Further qualitative studies are needed on the current sample on the parents and children's home computing behaviour such as setting and following any home computer regulations.

\section{References}

Anderson, C., \& Bushman, B. (2001). Effects of violent video games on aggressive behaviour, aggressive cognition, aggressive affect, physiological arousal, and prosocial behaviour: A meta-analytic review of the scientific literature. Psychological Science, 12, 353-358.

Azevedo, R. (2005). Computer environments as metacognitive tools for enhancing learning. Educational Psychologist, 40, 193-197.

Bose, K. (2017). Developmentally Appropriate Technology in Early Childhood (DATEC) in Botswana: In-Service Teachers' Perspectives. International Electronic Journal Of Elementary Education, 1(3), 218-231.

Browne, K., \& Hamilton-Giachritsis, C. (2005). The influence of violent media on children and adolescents: a public-health approach. Lancet, 365, 702-710.

Coffey, G. (2017). Literacy and technology: Integrating technology with small group, peer-led discussions of literature. International Electronic Journal Of Elementary Education, 4(2), 395-405.

Colwell, J., \& Payne, J. (2000). Negative correlates of computer game play in adolescents. British Journal of Psychology, 91, 295-310.

Culnan, M. J., \& Markus, M.L. (1987). Information technologies. In Jablin, F., Putnam, L. L., Roberts, K. \& Porter, L. (Eds.). Handbook of Organisational Communication. Newbury Park, CA, Sage.

Dillon, A., \& Jobst, J. (2005), Multimedia learning with hypermedia. In Mayer, R.E. (Ed.) Cambridge handbook of multimedia learning. New York, Cambridge University Press.

Dubrovsky, V.J., Kiesler, S. \& Sethna, B.N. (1991). The equalisation phenomenon: Status effects in computer-mediated and face to face decision-making groups. Human-Computer Interaction, 6, 119-146.

Ersoy, A., \& Bozkurt, M. (2017). Understanding an elementary school teachers' journey of using technology in the classroom from sand table to interactive whiteboard. International Electronic Journal Of Elementary Education, 8(1), 1-20.
Facer, K., Furlong, J., Furlong, R. \& Sutherland, R. (2001). Home is where the hardware is: Young people, the domestic environment and 'access' to new technologies. In Moran-Ellis, I. H. A. J. (Ed.) Children, Technology and Culture. London, RoutledgeFalmer.

Fleming, M.J., \& Richwood, D.J. (2001). Effects of violent versus nonviolent video games on children's arousal, aggressive mood, and positive mood. Journal of Applied Social Psychology, 31, 2047-2071.

George, D. (1997). Working longer hours: Pressure from the boss or pressure from the marketers? Review of Social Economy, 55, 33-65.

Hadwin, A.F., \& Winne, P.H. (2001). CoNotesS2: A software tool for promoting self-regulation. Educational Research and Evaluation, 7, 313-334.

Holloway, S.L., \& Valentine, G. (2003). Cyberkids: Children in the Information Age. London: Routledge Falmer.

Huda, M., Jasmi, K., Hehsan, A., Mustari, M., Shahrill, M., Basiron, B., \& Gassama, S. (2017). Empowering children with adaptive technology skills: Careful engagement in the digital Information age. International Electronic Journal Of Elementary Education, 9(3), 693-708.

Irwin, A.R., \& Gross, A.M. (1995). Cognitive tempo, violent video games, and aggressive behaviour in young boys. Journal of Family Violence, 10, 56-69.

Kirriemuir, J., \& Mcfarlane, A. (2006). Literature review in games and Learning. Futurelab Series. Bristol, Futurelab.

Kraut, R.E., Patterson, M., Lundmark, V., Kiesler, S., Mukopadhyay, T., \& Scherlis, W. (1998). Internet paradox: A social technology that reduces social involvement and psychological well-being? American Psychologist, 53, 1017-1031.

Lajoie, S.P. (2000). Computers as cognitive Tools II: No more walls: Theory change, paradigm shifts and their influence on the use of computers for instructional purposes. Mahwah, NJ, Lawrence Erlbaum Associates, Inc.

Livingstone, S., \& Haddon, L. (2009). EU kids online: Final report. London, London School of Economics and Political Science.

Lo, S., Wang, C., \& Fang, W. (2005). Physical interpersonal relationships and social anxiety among online game players. CyberPsychology \& Behaviour, 8, 1520.

Mckenna, K.Y.A., \& Bargh, J.A. (2000). Plan 9 from cyberspace: The implications of the internet for personality and social psychology. Personality and Social Psychology Review, 4, 57-75.

Malamud, O., \& Pop-Eleches, C. (2008). The effects of computer use on child outcomes. Computers and Education, 35, 159-167.

Mitchell, E. (1985). The dynamics of family interaction around home video games. Special issue: Personal computers and the family. Marriage and Family Review, 8, 105-115.

NIE, N.H. (2001). Sociability, interpersonal relations, and the internet: Reconciling conflicting findings. The American Behavioural Scientist, 45, 420-435. 
Nie, N.H. \& Erbring, L. (2000). Internet and society: A preliminary report. Stanford, CA, Stanford Institute for Quantitative study of Society.

Noroozi, O. (2017). Considering students' epistemic beliefs to facilitate their argumentative discourse and attitudinal change with a digital dialogue game. Innovations in Education and Teaching International. http://dx.doi.org/10.1080/14703297.2016.120811 2.

Noroozi, O., Biemans, H.J.A., \& Mulder, M. (2016). Relations between scripted online peer feedback processes and quality of written argumentative essay. Internet and Higher Education, 31, 20-31.

Noroozi, O., Biemans, H.J.A., Busstra, M.C., Mulder, M., \& Chizari, M. (2011). Differences in learning processes between successful and less successful students in computer-supported collaborative learning in the field of human nutrition and health. Computers in Human Behaviour, 27(1), 309-318.

Noroozi, O., Kirschner, P., Biemans, H.J.A., \& Mulder, M. (2018). Promoting argumentation competence: Extending from first- to second-order scaffolding through adaptive fading. Educational Psychology Review, 30, 153-176.

Noroozi, O., \& Mulder, M. (2017). Design and evaluation of a digital module with guided peer feedback for student learning biotechnology and molecular life sciences, attitudinal change, and satisfaction. Biochemistry and Molecular Biology Education, 45(1), 31-39.

Noroozi, O., Weinberger, A., Biemans, H.J.A., Mulder, M., \& Chizari, M. (2012). Argumentation-based computer supported collaborative learning (ABCSCL). A systematic review and synthesis of fifteen years of research. Educational Research Review, 7, 79-106.

Noroozi, O., Biemans, H.J.A., Weinberger, A., Mulder, M., \& Chizari, M. (2013a). Scripting for construction of a transactive memory system in multidisciplinary CSCL environments. Learning and Instruction, 25(1), $1-12$.

Noroozi, O., Teasley, S.D., Biemans, H.J.A., Weinberger, A., \& Mulder, M. (2013b). Facilitating learning in multidisciplinary groups with transactive CSCL scripts. International Journal of Computer-Supported Collaborative Learning, 8(2), 189-223.

Noroozi, O., Weinberger, A., Biemans, H.J.A., Mulder, M., \& Chizari, M. (2013c). Facilitating argumentative knowledge construction through a transactive discussion script in CSCL. Computers and Education, 61, 59-76.

Passey, D., Rogers, C., Machell, J., Mchugh, G., \& Allaway, D. (2003). The motivational effect of ICT on pupils, London, Department for Education and Skills.

PEW. (2000). Tracking Online Life: How women use the internet to cultivate relationships with family and friends. Washington DC, PEW Internet and American Life project.

Piaget, L. (1978). The development of thought: Equilibration of cognitive structures. Oxford, Blackwell.

Pintrich, P.R. (2000). The role of goal orientation in self-regulated learning In Boekaerts, M., Pintrich, P.R. \& Zeinder, M. (Eds.) Handbook of Self-regulation. New York, Academic.
Rogoff, B. (1997). Apprenticeship in thinking: Cognitive development in social context. New York, Oxford University Press.

Reiber, L.P. (2005). Multimedia learning in games, simulations, and microworlds. In Mayer, R.E. (Ed.) The Cambridge Handbook of Multimedia Learning. New York, Cambridge University Press.

Säljö, R. (1998). Thinking with and through artefacts: the role of psychological tools and physical artefacts in human learning and cognition. In Faulkner, D., Littleton, K. \& Woodhead, M. (Eds.) Learning Relationships in the Classroom. London, Routledge/Open University.

Selwyn, N., \& Facer, K. (2007). Beyond the digital divide, rethinking digital inclusion for the 21st century, Opening Education. Bristol, Futurelab.

Shaw, L., \& Gant, L. (2002). In defence of the internet: The relationship between internet communication and depression, loneliness, self-esteem and perceived social support. CyberPsychology, 5, 157-171.

Short, J., Williams, E., \& Christie, B. (1976). The social psychology of telecommunication. London, John Wiley.

Schunk, D.H., \& Ertmer, P.A. (1999). Self-regulatory processes during computer skills acquisition; goal and self-evaluative influences. Journal of Educational Psychology, 91, 251-260.

Song, S.H., \& Keller, J. M. (2001). Effectiveness of motivational adaptive computer-assisted instruction on the dynamic aspects of motivation. ETR\&D, 49, 5-22.

Sproull, L. \& Kiesler, S. (1986). Reducing social context cues: Electronic mail in organisational communication. Management Science, 32, 40-52.

Steiner, G.A. (1963). The people look at the television: $A$ study of audience attitude. New York, Knopf.

Steinfield, C.W. (1986). Computer mediated communication in an organisational setting: Explaining task-related and socio-emotional uses. IN Mclaughlin, M.L. (Ed.) Communication Year Book 9. Newbury Park, CA, Sage.

Subrahmanyam, K., Greenfield, P.M., Kraut, R.E., \& Gross, E.F. (2001). The impact of computer use on children's and adolescents' development. Applied Developmental Psychology, 22, 7-30.

Subrahmanyam, K., Kraut, R. E., Greenfield, P. M. \& Gross, E. F. (2000). The impact of Home Computer Use on Children's Activities and Development. The Future of Children, 10, 123-144.

Sylva, K., Melhuish, E., Sammons, P., Siraj-Blatchford, I., \& Taggart, B. (2008). Final Report from the Primary Phase: Pre-school, school and family influences on children's development during key stage 2 (Age 7-11). London, DCSF.

Turkle, S. (1995). Life on the screen: Identity in the age of the internet. New York: Simon \& Schuster.

Turow, J., \& Nir, L. (2000). The internet and the family 2000: The view from parents, the view from kids, Report No.33. Philadelphia, PA, The Annenberg Public Policy Centre.

Valentine, G., Marsh, J. \& Pattie, C. (2005). Children and young people's home use of ICT for educational 
purposes: the impact on attainment at key stages 1-4. London: DfES.

Walther, J.B. (1995). Relational aspects of computer-mediated communication: experimental observations over time. Organisation Science, 6, 186-203.

Wartella, E., Caplovitz, A.G., \& Lee, J.H. (2004). From baby Einstein to leapfrog, From doom to the sims, From instant messaging to internet chat rooms: Public interest in the role of interactive media in children's lives. IN SHERROD, L. (Ed.) Social Policy Report. Society for Research in Child Development.

Whipp, J.L. \& Chiarelli, S. (2004). Self-regulation in a web-based course: A case study. ETR\&D, 52, 5-22.

Wiegman, O. \& Van Schie, E. (1998). Video game playing and its relations with aggressive and pro-social behaviour. British Journal of Social Psychology, 37, 367-378.

Winters, F.I., Greene, J.A., \& Costich, C.M. (2008). Self-regulation of learning within computer-based learning environments: A critical analysis. Educational Psychology Review, 20, 429-444. 